\title{
Commercialized Security and Its Role in Selected Countries' National Security
}

\author{
Gerald Peter Mutonyi ${ }^{1}$, Casper Masiga ${ }^{1}$, Happi Kilongosi ${ }^{2}$ \\ ${ }^{1}$ Kenyatta University \\ P. 0. Box 43844-00100, Nairobi, Kenya \\ ${ }^{2}$ University of Nairobi \\ P. 0. Box 30197-00100, Nairobi, Kenya
}

DOI: $10.22178 /$ pos. $60-6$

JEL Classification: K40

Received 26.06.2020

Accepted 28.07.2020

Published online 31.07.2020

Corresponding Author:

Gerald Peter Mutonyi

mutonyig@gmail.com

(c) 2020 The Authors. This article

is licensed under a Creative Commons

Attribution 4.0 License @) (1)

\begin{abstract}
The complexity of the contemporary world has dictated the commercial security to supplement the supply of security in states. This is for the varied security needs of the citizens to be fulfilled. Hence this study embarked to illustrate the various roles of commercialized security in the national security of selected countries: the USA, Britain, Australia, Israel, South Africa, DRC, Tanzania, Uganda, and Kenya. The study has shown that the scope of commercialized security has expanded, thereby taking up some roles that require and some that do not require to be carried out by the state security agencies. This is partly due to its embracing of technology and enormous numbers of personnel than the state security agencies. But realistically, the state will not be losing its monopoly of violence, but distributing it to the commercialized security through a network of governance and partnership. This trend will continue and will be of direct benefit to the state's ability to influence its security. Based on the findings, the study recommends effective regularization of commercial security as well as collaboration between state security agents.
\end{abstract}

Keywords: Commercialized Security; Commercialized Security Industry; Commercialized Security Services; State Security Agencies; National Security.

\section{INTRODUCTION}

The contemporary model of national security goes back to the seventeenth century when Hobbes ushered in the social contract, where the moral obligations on the sovereign were to preserve and protect the lives of people and property [60]. Providing security as the most significant responsibility of the state was also influenced by the views of Max Weber. The 'Weberian State' had the exclusive monopoly of the rightful application of violence [44]. Consequently, the state was acknowledged to be culpable for providing internal security and defense from external threats. In that regard, maintaining good order and security in a nation is presently an undertaking of establishments that traditionally have been referred to as 'National police' [25]. But the growth of societies and the complexity of urban life has required that there be a transfer of some services provided by the police. Therefore, a variety of actors are in particular looked upon to complement the provision of security services. Arguably, the most important of these actors is the commercialized security industry (CSI), which has developed considerably in both developing and developed nations. Some researches have associated the development and enlargement of commercialized security consumers with insufficiencies in the capability of states to successfully supply security-related services $[1,6]$.

The nation's organizations are also restricted in guaranteeing impartiality in the transmission of security to all its inhabitants and visitors [9]. Consequently, countries focus the provision of security to their important assets and some individuals, whereas the rest of the populace and their possessions are settled in a one fit all outfit notwithstanding, their diverse security requirements. Similarly, the diverse security requirements by the populace attach various burdens that are over and above the capacity of states, thus making it difficult for matching provision of 
security service [9]. As law implementation resources are being overstressed, it obligates more collaboration with the private industry and with its security assets to mutually create a partnership on an identical base for crime deterrence and decrease [86, 50, 88].

Nowadays, an inclination to rely on commercial firms to provide security services has increased, even more, growing rampantly in the course of the last two decades [82]. Several reasons have been forwarded by scholars to explain this phenomenon. The close of the cold war was constituted by enormous downscaling of the defense spheres: fewer troops being a requisite, and smaller militaries decreased security linked expenditures for nations and the downscaling of security agencies broadened the source of trained personnel that subsequently was fervently required by commercial security firms (CSFs) involved in the security enterprise [79]. The increasing trend towards the commercialization of security has already spread all over the world. Concurrently, the pulling out of major supremacies from particular territories in the world, the advent of new warfare in the developing nations in the period of the 1990s, and the inclination to subcontract military training, inspired the inclusion of the commercial security providers in war zones [79]. Some researchers have stated that the development of the commercialized security industry in Africa is "symptomatic of state weakness and the failure of the state to provide physical security for its citizens through the established and functioning security institutions" [32]. Others have highlighted the argument that commercialized security grows in an environment of the presence of parallel arrangements of supremacy or power [70]. But there are indications that the citizens have reckoned that the state security agencies do not avert criminality and should not be presumed that they will. Consequently, globalization and a series of other influences were causing the commercialization of security functions.

Wilson and Slater advanced a classical definition of commercialized security as, "The safeguarding of assets, personnel and even profitability of the organization against theft, fire, fraud, criminal damage and terrorist acts" [58]. A commercial security firm is a registered civilian enterprise that has specializations in the providence of contracted commercial security services to national and foreign bodies to protect their personnel and humanitarian and industrial assets as directed the regulations of appropriate national law [24]. It has also been defined as, an enterprise that provides some aspect of security/policing services with a profit motive [84]. Whereas others have described it as commercial security as feepayment services intended at protecting people and properties $[9,88]$.

While this phenomenon is a concern for some, the mandate of commercialized firms to deliver safeguard is not new, as it is a method that precedes the founding of societal funded, nationally controlled police services [53]. Previously a century ago, security guards and night watchmen were safeguarding people in the town of central Europe. Furthermore, in house security guards were common in manufacturing establishments of that period [16]. However, while commercial security guards were inaugurated and managed in Britain by a magistrate, Henry Fielding, they were wholly financed by the rich business people, and in that consideration, they were 'commercialized security' [53]. Following Fielding's resourcefulness, many rivaling organizations were founded, with well-to-do traders employing armed personnel to make the rounds. It was observed that assets were perceived as being 'private' and therefore not needing the state's protection. Consequently, the obligation and accountability were on the owner to offer suitable safeguards.

Across the Atlantic Ocean in the United States of America (USA), 'private policing' firms rose from the awareness that the state security agencies were compromised by the ruling elites, and were also insufficient or dishonest to safeguard the welfares of the dominant industrialists [25]. Security had not only been privatized but also commercialized, in that it is predominantly about securing economic resources and is an economic activity. By 1892 the number of commercial policing firms had increased to 15 in Chicago and 20 in New York [53]. This was taking place at the time when the state security agencies were also being created, and they, therefore, progressed in parallel.

The commercialized security industry is now a major phenomenon around the world, with security guards in their employment. An analysis of 70 nations, made estimates that the formal commercial security sector employs between 19.5 and 25.5 million people in the world [28]. Indeed, the activities carried out by the commercialized security sector are vast, with security products 
and systems such as manned security guarding, alarm and electronics, cash and valuables in transit, consultancy, and investigation. As has been argued that, worldwide no security operation is performed by the state security industry, that is not carried out by the commercialized security industry in some way [12]. There exists an array of non-state law enforcement players who are involved in different forms in 'policing'.

The current literature incorporates diversified sources of information to explore the various functions and roles of the industry in selected countries of the USA, Britain, Australia, Israel, South Africa, DRC, Tanzania, Uganda, and Kenya.

\section{RESULTS AND DISCUSSION}

\section{Commercialized Security and its role in the USA's National Security}

Accordingly, the existing data suggest that the use of commercialized security in the USA started in 1850 when Allan Pinkerton founded the Pinkerton National Detective Agency, a private detective firm in 1850 . He, later on, became famous for foiling a conspiracy to assassinate then President-elect Abraham Lincoln in 1861 [11]. Pinkerton's national detective personnel provided services ranging from detection of criminality and covert investigations. The agency offered endorsed services for safeguarding the railroads, to plant protection and armed security in the country.

As for the alarm and electronic services, as ar form of commercialized security service in crime deterrence, the first y alarm firm was founded in 1858 by Edwin Holmes, then the American Daily Telegraph (ADT) was established in 1874 [11, 19]. Another organization to offer commercialized security service in the USA was The William J. Burns Detective Agency in 1909 [11]. Thus the early commercialized security industry in the USA provided several functions that are currently linked with state security agencies, for instance, investigating crimes, guarding interstate railroads and shipments, and providing security guidance to banking institutions and other organizations that were habitually targeted by the criminals.

Nations like the USA, Britain, and Canada attained a turning point of their criminality regulation and law enforcement evolution in the 1960s, and this is when the states' monopoly on security providence was breached by the creation of agents in the community to prevent crime by investigating offenses, deterring criminals and catching lawbreakers [7]. Between the year 1972 through to 1977, the Law Enforcement Assistance Administration of the U.S. Department of Justice leased the services of the Private Security Advisory Council "to improve on the crime prevention competencies of the commercialized security industry and decrease crime rates in private and public spaces by the review of the relationship amongst the state security agencies and the commercial security players, and by advancing plans and guidelines concerning the commercial security services that are suitable and reliable with the interest of the public" [36]. That is how beneficial the role of commercialized security was being perceived by the state. Certainly, the fitting of domestic security systems in the USA, furthermore doubled over a five-year duration in the 1990s [17]. The federal and local governments also sought the services of commercial security firms. During the 1950s, the city of Kalamazoo, Michigan, procured the services of private police agents as deputy sheriffs and it is believed that it was the first local government entity to undertake it [38]. Up to the 1990s, it was estimated that $45 \%$ of the local governments procured most of their security services from the commercialized security industry, in comparison with a $27 \%$ during the 1980s [83]. This principle became common as numerous commercial security guards were engaged to safeguard the public housing groups, state's buildings, and the public parks. For example, Wackenhut Corporation had contracts to offer security personnel for the Liberty Bell in Philadelphia and to screen visitors at the Statue of Liberty in New York City [26]. The federal and local governments, therefore, have contributed to the growth and development of the commercialized security in their jurisdictions, when they seek the services of the industry. They seek such services so that, they may be able to control the public spaces so that harm and danger do not befall those having legitimate access to such spaces.

Approximately 150 cash and valuables in transit (CVIT) firms operated in the USA [20]. CVIT firms in the previous years provided armored vehicles and armed crew to secure and distribute jewelry and other precious metals, currencies, securities, bonds, credit cards, and other items of high intrinsic value [14]. These exercises also included 
sorting, counting, and packaging the cash from automatic teller machines or emptying parking meters [14]. The safekeeping delivered by these enterprises comes with great dangers due to the threats involved during the transportation of the resources. Accordingly, 70 armed robberies would occur each year in the CVIT industry resulting in an average of 5 deaths of CVIT crew [17]. Despite the risks in this service, the CSI continues to ensure that the economy of the USA is sufficiently supplied with the necessary valuables of trade. Also, the citizens and visitors are living comfortable lives by accessing and using their valuables.

The role of commercial security guards in the USA's counterterrorism readiness is a subject that has not been extensively researched and well understood, but it was a matter of citizen's debate in New York in 2005. United Voice is quoted saying that, in that year, the New York's city council made a declaration that "commercial security officers displayed great bravery and expertise when they endangered their lives to preserve order, move out thousands of people and help rescue lives" [35]. When all was finished, 42 security personnel had died from the Twin Towers attack. And hence, more commercial security personnel lost their lives on the attacks on the World Trade Center than the New York police agents, whereas they work for far less pay, very littler remunerations and provisions, and with much less social commendation and honor in the society [35]. There have been several other companies, for example, in 2004 the Central Intelligence Agency (CIA) is alleged to have involved Blackwater (which revised its identity to Xe in 2009 and Academi in 2011) in a secret program to track down and eliminate members of the $\mathrm{Al}$ Qaeda network [45]. In Iraq and Afghanistan, the US intentionally chose to contract commercialized security firms to take on "unforeseen" tasks, to throw/cast caution to the wind(s), and to "act similar to soldiers, not businessmen". But the impact of these militarized commercial security entities' involvement on 'the war on terror', is still scarce.

Despite all these, according to the Private Security Advisory Council (PSAC) in the USA, the CSI has been unsuccessful in promoting higher levels, and better standards of educational fulfillment because of the absence of stable regulation [55]. Hence it would be of great interest to know how the consistency of regulations of commercialized security between states would affect the overall impact of the industry on national security.

\section{Commercialized Security and its role in Britain's National Security}

Britain's commercialized security is a principal authority, a high-technology segment that has quickly grown. Indeed, the Britain security industry has over the year expanded five times quicker than the other sectors of Britain's economic sector ever since 2010 [29]. Firms in service in the security industry have devoted themselves to revolutionizing and changing principles to ensure that the sector is continually respected worldwide. It is currently extensively regarded as leading in revolution and expertise in security services and products. It has been observed that there has been a change from wholly exclusive dependence on the state security agents to "selfdefense" or "responsive safekeeping" [89]. This is one of the explanations for the fast expansion of commercialized security, despite the fact of an overall decrease in crime rates in Britain.

In the UK, some responsibilities previously undertaken by the state security agents are being subcontracted in an endeavor to minimize the expenditures of policing [64, 87]. This includes outsourcing CSFs in undertaking beat patrols, testifying in court, and in contacting criminal investigations. This is defined as, "venturing further than the customary subcontracting, as it pulls on the expertise, skills, innovation, and technology of the commercial industry to back the end-to-end revolution of security service provision within organizations, to make better the services to the citizens" [49]. The phrase "business partnering" has therefore been conceived to represent the associations that are existent amongst the state security agents and the commercial security agents.

Some security firms are targeting more elite consumers in London's most upmarket areas, who can pay for increased safeguarding above what the government provides. This was even acknowledged by the Labour party shadow home secretary, Diane Abbott that, that very few living in gated communities having their commercialized security suffer less from crime, unlike the ordinary citizen [68]. This demonstrates the important role of commercialized security in Britain. The leader of the opposition Labour party Jeremy Corbyn during one of his campaigns had 
indicated that, if his party was going to win the upcoming election, it was going to add 10,000 extra police agents to the current security agents so that the citizens would enjoy the safety that those able to procure commercialized security were achieving.

Commercialized security was being so successful in the UK that according to the Confederation of European Security Services (CoESS), there was 232,000 commercial security personnel in 2015 rivaling the figure of secondary school teachers who were roughly 250,000 [68]. And they far exceeded the levels of police officers in Britain who in March 2016, were totaling 151,000 [68]. The figures of the commercial security personnel in comparison to the one for teachers inform a lot about the necessity of their services and the fragility of their consumers. In comparison to the numbers of the police, it might be informing the confidence the consumers have in the industry or the inability of the state to be able to engage enough police to assure the citizens and the visitors of their security. Consequently, some consumers in one Essex town had supposedly contracted commercialized security to watch over public streets during the night when their local police station shut [68].

The commercialized security while giving a Fourth Report of Session 2012-13 to the Home Affairs Committee emphasized that they have on most times been engaged in locating witnesses, serving individuals with court papers on the support of attorneys and legal representatives, obtaining evidence for use in court and reconnaissance and background checks on behalf of law firms [33]. The Home Affairs Committee was told that commercial security investigators have been helping to save billions of pounds for United Kingdom corporations, citizens, and the economic sector from their role in the detection of frauds. For instance, Cerberus company was mentioned as a key factor in the recovery of stolen goods and defending intellectual property rights. It was also stated that the losses of over $£ 2$ billion suffered by the insurance industry through fraud, could be curtailed by the role played by the commercialized security [33].

The Home Affairs Committee was informed that, if the belief that the police cuts were going to take effect, then the commercial security industry would step into the void, most of the time being assigned cases that are of utmost importance to the public, and which may be too complicated or too small for the state security agencies to devote to. It was even recommended that, in London, the City of London Economic Crime Unit, the Metropolitan Police and the Serious Fraud Office might not be investigating economic frauds because of limited resources except where "very substantial sums of money" were involved [33]. In Britain wherein there are divisions in terms of responsibilities between the state security agents and the commercial security agents, it can be stated that such modalities help to reduce crime rates. Consequently, this police-commercialized security collaboration in Britain has on some occasions lead to crime decrease [63]. In such a structure, subcontracting certain tasks to the commercialized industry is complementing the work of state security agents. In the Manchester, terrorist attack at a concert arena in 2017, the denial of entry of the bomber to the auditorium by the commercial security guards reduced the number of fatalities. The commercial security guards also provided first aid that saved lives after the bomb was detonated in the lobby [52].

A study in the UK established that the state security agents induced the highest levels of citizen assurances in private and public space like the shopping malls as compared to the other cadres of commercial security personnel [73]. Even though the citizens were contented with commercial security agents, there were reluctant with the need to expand their security influences. The inclination was for the commercialized security to have a complimentary duty to the state security agencies [57]. This raises the questions as to the reasons behind citizens wanting the commercial security industry to be curtailed whereas it has been known for its role in crime reduction.

Perhaps, the utmost significant development in Britain's commercialized security has been the institution of the state's regulation through the Security Industry Authority (SIA) instituted in 2003. The commercial security firms in Britain are fully compliant with the law and take seriously consider legal requirements such as the Modern Slavery Act, the UK Counter-Terrorism and Security Act, and the UK Bribery Act. They are successfully operating in the sector the Ministry of Defense and the British Army have the confidence to do business with them. 


\section{Commercialized Security and its role in Australia's National Security}

The commercialized security sector in Australia has been responding in an intensely on the increasing demands for specialized safeguarding roles. The 1980s and 1990s saw an expansion of the industry with information illustrating that commercial security guards currently outnumbering the police agents by two-or-more to one [28]. Commercial security as a whole has an estimated annual turnover in Australia of more than $\$ 8$ billion: $\$ 4$ billion in the manpower sector, and $\$ 4$ billion in the electronics sector [8]. The commercial security industry in some capacities has resources and capabilities beyond those of state. It has the bulk of personnel responsible for the protection of assets and for providing speedy reaction to an occurrence. It is endowed with the bulk of senior managers and advisers having formal qualifications and certified in proactive security.

The growth in commercial security has been attributed to a wide variety of factors. The current upward trend in criminality, and particularly asset crime, has also been nearly been linked with the consumption of commercial security and the continuous development in the industry [89]. The foremost influence appears to be the market requirement, compelled by the broad surges in crime as from the 1960s throughout the century. Surges in criminality has, in turn, been linked with the increase of richness and personal mobility that occurred during this period [91]. The development of 'mass private property' locations, such as shopping centers and sports stadiums, was an additional aspect, so were the advances in security technology, legislations of the place of work safety standards, multiplied lawsuits by victims of insecurity, and the post-Munich and post-9/11 terrorist threats [67].

In Australia, the commercial security industry provides varied activities that were before a preserve of the state security agents. Such include crowd control, manned guarding and patrolling installations, risk management, court security, criminality deterrence, evidence-gathering, and incident investigations [75]. Commercial security providers and professionals perform a principal role in protecting crowded places. In many cases, commercial security professionals are having the authority and directly liable for the reinforcement of the security of crowded spaces. As a result, they have to be well-trained and profes- sional in their performance. They are relied upon more for their expertise to protect critical infrastructures, for instance, defense installations, airports, government sites, private-sector venues. And more often, they are the first responders to acts of terrorism incidents [75].

There is a considerable partnership on security in Australia between the state securitycommercial security, which has noted trends toward greater cooperation. Some of the collaborative examples include:

The "Eyes on the Street" initiative which is an insecurity deterrence program in Western Australia, comprises a collaboration between the state security agents, the local governments, the private business community, and the commercial security sector. It rallies the determinations of all of the stakeholders to share incidents with the state security agencies and to make available data that can assist in apprehensions [67].

The Ipswich (Queensland) Safe City initiative is pegged on a CCTV infrastructure supervised by a contracted commercial security company. The program was intended to mitigate against chaos in the city Centre. The control base is connected to the police and the commercial security personnel, and the initiative is also focused on insecurity deterrence [67].

A review of the experience of the state security agencies and the commercial security in Australia concluded that there was strong evidence suggesting that they can work successfully with each other in lessening of crime. This commentator continues to state that, the commercial security sector has made a substantial impact to the decrease in insecurity rates, and that the key stakeholders in this initiative have been the local and central governments, the state security agencies, commercial security firms, and several private industry actors, such as the business associations [64]. Indeed, the IBISWorld report detailed several of the sector-specific tendencies that are most probable to endure, for example, substantial ongoing development in alarms and electronics, CCTV surveillance and control, as they are perceived to be extra cost-effective as compared to manned guarding, and manned guarding services will have decreased the growth for both patrol and static, an increase of cash and valuables-in-transit security demand partly as a result of the multiplication of automatic teller machines, and continued low entry prohibitions to business [37]. 
Australia's national terrorism threat level has been 'Probable-terrorist attack is likely' [8]. Despite the persistent threats of terrorist attacks on the Australian territory, the commercial security industry who have been the nation's 'eyes and ears', have been excluded from the nation's counter-terrorism strategies. Most funds allocated to the strategies have been solely for state security agencies and emergency responders. The commercial security guarding personnel have already been contracted to carry out actions that assist in preventing and responding to terrorist occurrences, but they currently lack consistent abilities to perform those responsibilities. For them to be enabled to undertake the counterterrorism functions, there's a need for improved inclusive polices.

There has been a witness to several problems associated with the commercial security sector in Australia. Inquiries into the industry, by the Australian Crime Commission, the New South Wales Independent Commission against Corruption, and the Fair Work ombudsman identified some of them. There was the possibility of criminal activities and the infiltration of commercial security by the organized criminal cartel, mistreatment of security personnel through low remunerations, and corruption in security personnel training systems [65]. There were also concerns that there was criminal infiltration of the commercial security industry in some jurisdictions [65]. Fraud, corrupt habits, insider crimes, trading in illicit merchandise, and money laundering are of certain interest [49]. These probes heightened both the risk profiles of the commercial security sector in Australia.

Complications linked with the commercial security personnel, guns and protection persisted through the 1990s into the 2000s. For example, in 1998, a gunfight between armed robbers and armored vehicle security crew in a crowded Brisbane street occasioned in several injuries, comprising a permanent paralysis of a passer-by [62]. Similarly, in 1987, an incident in Adelaide, where a customer in a jam-packed street was shot by a security guard who was aiming at intruders [74]. Between 2003 and 2005, in New South Wales, there were several thefts of weapons from security personnel and the premises of security organizations. In a three months' duration in 2007, 56 guns were lost in six instances [66]. An Australian Crime Commission (ACC) 'special intelligence operation' into criminal infiltration of the sector, which commenced by Sep- tember 2007, and finalized its report by June 2009 , identified cases across the country of organized criminal individuals possessing security businesses or 'buying off or corrupting security company's or their personnel' [59]. Key reforms in these spheres are crucial if these problems of violence within the licensed firms that adversely taints the whole industry were to be addressed adequately. There is the necessity for a spirited regulation of the sector to guarantee the maximum probable ideals of operations. New licensing settings, stringent screening checks, and harmonized and intensive training requirements, and all inconsistent with the current emerged international ideals of best industry practice regulation.

While it is evident that, there have been laws of regulations instituted in all of the Australian territories regarding the registration and licensing of commercial security practitioners, the main aim of these laws is to regulate the operations within the industry. But the provisions are inconsistent between jurisdictions, for instance, the application of force in defense of property, In South Australia, in the Queensland, in Western Australia, New South Wales, and Victoria. As noted above, in most areas in Australia different traits of legislations are in place.

From the national perspective, however, the regulation remains fragmented, with little indication of reliable developments in the industry. The government has a role in supporting the commercial security industry to achieve this, including by preserving a strong supervisory authority around registration, training, and employment [4]. A much more proactive attitude is needed to achieve quality results in the provision of crucial security services.

\section{Commercialized Security and its role in Israel's National Security}

The commercialization of the security sector was being undertaken in Israel in towards the end of 1980 s and beginning of 1990s, as a result of the economic and technological evolutions, as well as emanating political turmoils, which encouraged for a renewal of the evaluation of the Israel Defense Force (IDF) responsibilities [71]. Thereafter, the Sadan Committee's report of 1994, the Brodet Committee's report of 2007, endorsed that responsibilities undertaken by the armed force to be liberalized to the civilian sector, and 
measures sanctioned to oversee the fulfillment of this objective. In November 2000 the state of Israel sanctioned a resolution whereby, the IDF would recommend the roles that would be carried out by the civilian industry while considering their consequences. Consequently, the subcontracting of security services commenced with food laundry, catering, and transportation, and is then extended to the manufacture of armed forces systems, with the inclusion of the dividing barrier [71].

Commercialized security in Israel performs an active role in the nation. They manage checkpoints and secure settlements in the West Bank and East Jerusalem. The central roles in which the commercialized security industry performs security roles in Israel and the West Bank are:

1. The daily controls of the passages/checkpoints linking Israel and the West Bank, and linking Israel and the Gaza Strip. The justification is that the privatization of the passages would come along with the professionalism of procedures, and thereby enhance the level of service provided to the Palestinians crossing over. The aims of privatization of the linkages are mostly stated these days as, awareness of service quality, efficiency, and enhancing the level of service to Palestinian citizens [69]. For instance, there is an inclination for the commercial security guards who have a mastery of either spoken or written Arabic, which would assist them in communicating effectively with the Palestinian residents and also read their official papers [10].

2. Protection of numerous private and public institutions in Israel, and in the West Bank settlements. Regarding state and public utility office blocks, this practice is in sync with global practices and goes back to the founding of the state. It extended to a range of other institutions at the beginning of the 1990s, after the breakout of the first intifada that manifested itself in remotecontrolled bombs and suicide bomb assaults on cafés, bus stops, buses, market against civilians [71]. In the settlements of West Bank and East Jerusalem, the commercial security personnel, who are contracted by the government of Israel, safeguard the settlements and de facto serving as a policing agent that serves the settler's people. The engagement of commercial security firms allows state establishments to deliver security services exclusively to the settlers, excluding the security needs of the Palestinian populations nearby the settlements. This position creates natural discrimination amongst the Jewish population and the Palestinians in East Jerusalem and the West Bank, which in itself becomes a source of insecurity to the settlers and the Israeli nation.

3. The government's decision of 1995 had placed the obligation for safeguarding learning institutions on the state security agencies but as time went by, several of these security services (including learning institutions) have been commercialized. Handels is quoted as stating that, in 2008 , for example, $21.1 \%$ of the police's expenditure budget went to the commercial contracted services even though they are inclusive of more than security services [81]. The outbreak of the second intifada in 2000, strengthened this preference, occasioning to a major increase of some commercial security guards (nearly threefold from 1995 to 2003) [81].

4. Protection of the building of the dividing barricade in the West Bank from 2003. The obligation for security services was the responsibility of the contractors [71]. They, therefore, engaged the commercial security firms to ensure their safety.

5. Securing the old city in Jerusalem, and in Jewish housing territories in East Jerusalem. Safeguarding in East Jerusalem is implemented under the umbrella of the housing ministry, which subcontracts the services to the commercial security industry. The security procedures of this ministry regardless of whether they are implemented by the commercial service providers or directly by the ministry personnel are however subjected to review by a committee selected in 2005 by the then housing minister [71].

Up to 2005, commercial security personnel had no legal power to request that people identify themselves, to search people's properties, or to restrain a person [71]. In 2005, the Powers for Maintaining Public Security Law 2005, was legislated and it empowers for the application in 'order to maintain public security against terrorist activity and violence'. The Law of Authorities for the Protection of Public Security (2005) spreads the powers of commercial security personnel in border frontier posts to comprise the powers to demand identification, search belongings for arms and explosives, delay a person, forcefully detain an individual until a police officer arrives and even conduct body searches [5].

As these commercial security agents are contracted by local councils and the settlements' regional, they tend to favor their interests, habitu- 
ally in ways that contrast with their responsibilities as agents of the law and guardians of public order [31]. This conflict of interest is always a recipe of daily disagreement and clashes between the commercial security agents of the settlements on one side and the Palestinian inhabitants on the other.

As illustrated, the commercial security sector in Israel is enormous and lucrative, due to among other factors its broad association in Israel control and surveillance of the Palestinian population. The Israeli government's vast policy of commercialization feeds to the security firms' development in investment and power and diminishes the state's accountability for security tasks when policing the Palestinians. In this regard, commercial security firms become a crucial element of the Israeli occupation.

Commercial security in Israel is liable to licensing by the statutory committee, under the act regulating the delivery of security services. Their conduct is moreover governed by contractual obligations with their customers. Ever since 1998 , the security providers are regulated by the law and they are designated as civilians who are not flat out engaging in conflicts since their affairs are law-enforcement rather than a warfare affair.

\section{Commercialized Security and its role in South Africa's National Security}

In 1868, diamonds were unearthed in the Vaal River, in the then Cape Province. There emerged an enormous demand for men who would be depended upon to safeguard these diamond tracts [90]. Men of African descent were conscripted to provide these security services. The shopping facilities also required these security services. The men did not have many skills, and all that was required was for them to be heavily bodied and with the ability to use a machete as a security weapon to prevent the criminals [61].

In the 1950s and 1960s, the banking institutions were hiring taxis to transport their valuables to or from the Reserve Bank of South Africa, and this was an era where robberies had escalated [42]. A strategy was founded by the business community to evade and lessen those criminality dangers which were being encountered, and Fidelity Guards commenced to provide the services for the transportation of valuables with vehicles having protection aspects having only one vehicle, and three male and one female crew [42].
Ten years later, the market demand for the cash and valuables in transit services grew and the Fidelity Guards security firm was not able to provide it all and therefore it joined with the Armored Car Services [90].

In 2002, the South African Banking Council established a commercial firm, the South African Banking Risk Intelligence Centre (SABRIC) (Pty) Ltd, to gather and analyze data on the modus operandi, location and type of CVIT and bank thefts to create solutions and mitigations to deter those types of crime [46]. Also, several firms specialized in this field, are supplying more sophisticated kits for the safeguarding of CVIT, for example, armored vehicles which have the abilities for rearview video camera surveillance, timed discharge of gas in the vehicles, in case of breaches dye discharge on opening valuables cases, all in a determination to better safeguard and stay ahead of the criminals and thwart the would-be CVIT robbers.

In terms of the commercial investigators in South Africa, there has been the prevalent usage and engagement of their services to solve some crime, and several exclusively investigative firms have been founded. They have mostly been manned by former police officers, who are devoted to the investigation of crimes and other cases for the particular purpose of assembling cases that would merely be forwarded over on completion for prosecution [46]. It is a frequent practice in South Africa, for those who can procure, to lease commercial investigators to gather data and locate suspects or even recover stolen items. Several murder cases of high profile have been resolved in this method of hired commercial investigators since the South African Police Service (SAPS) officers are so overwhelmed by cases, that they lack enough time to investigate every agenda, hence the victims are willing to employ a commercial investigator [46]. In some cases, commercial investigators are requested by organizations to solve in-house fraud cases, and several are an intricate embezzlement or fraud cases fraud in which the SAPS lacks the necessary technical, commercial expertise forensic and to examine such appropriately [46].

Accordingly, several security firms in South Africa provide an armed response, guarding services, electronic installers such as CCTV systems, electronic manufacturers and distributors, electronic fence and component manufacturers, close protection, cash management services, event se- 
curity, locksmith, in-house security and consumer goods protection [93].

Their activities are under a code of conduct for security service providers set by the Private Security Industry Regulation Act, No. 56 of 2001 and the regulatory body is the Private Security Industry Regulatory Authority (PSIRA). It is the most refined regulatory scheme set up on the continent regulating national commercial security and seen as an example by many other African countries of what prescriptive requirements should be enacted. Despite its broad scheme of regulation and information capturing system enabled by a recognized oversight body, South Africa still has difficulties in observing its almost two million security personnel on its database, because only roughly 400,000 are listed.

\section{Commercialized Security and its role in the Democratic Republic of Congo's National Security}

The population of the Democratic Republic of Congo (DRC) was approximately $78,700,000$ by 2017 , and this is a country that has been experiencing civil conflicts for a long time [85]. It is endowed with several mineral wealth such as gold, diamonds, gold, cobalt, and tin.

The Democratic Republic of Congo does not publish its crime data and as a consequence, criminal activities cannot be analyzed based on official criminal data like in the nations where the state security agencies publish official criminal data. Although in 2008 there were commercial security firms, there were no dependable statistics on the enlisted commercial security firms but there were about 45 commercial security firms, according to the existing statistics then, employing up to approximately 25,000 security guards [15]. In 2014, there were around 100 commercial security companies in the DRC, with over 30,000 security personnel in their employment [78].

Insecurity in a situation like Congo's, tend to be complicated by a police force that is inadequately trained and poorly resourced [15]. This creates the feeling of insecurity amongst the citizens and resulting in those who can buy it, to resort to the commercialized security. A majority of the commercial security firms are mainly providing security services to the urban areas whereas DRC is composed of enormous rural areas [15]. This can be as a result of high law-breaking proportions in urban regions in disproportional with low criminality proportions in the rural settlements, as is the case in numerous other nations. The main function of commercial security firms in DRC is crime deterrence done by patrols of the amenities, tracking of alarm and electronic systems and armed responses, reacting to accidents localities, rendering first aid when required, and to facilitate movement to the health amenities [15]. Part of the services by CSI for their consumers seems to be informal risk consultancy and the bigger CSFs furthermore offer evacuation services for when 'things take a wrong turn'.

Manned guarding through the visible presence of human guards, is, without doubt, the most important service provided, to the extent that security consultancy, electronic security, and cash-intransit are negligible (together constituting only about $5 \%$ of the total activities) [78]. Dakar, a firm operated by commercial security firm Blackwater's founder, has set up a branch in the DRC and is obligated to conduct financial operations and the exploration, exploitation, and commercialization of minerals, extract minerals, and forest logging [73]. Blackwater was sold in 2010 after some of its personnel were arraigned on illegitimate murder charges in connection with their duty as American state contractors during the war in Iraq.

CSFs form an intricate part of the system in which industrialized mining operations are structured in the DRC, with each mining site involving a security apparatus composed of dozens of CSF personnel supported by armed state security agents at a ratio of approximately 10:1 [77]. Commercial security firms therefore first manifested themselves around expatriates and furthermost especially in the mining sector because it was the most vital industrial sector in the country [15]. For example, in Province Orientale, there was over 1000 commercial security personnel deployed, and mostly concentrating around industrial mining organizations [78]. Beginning from 2013, there was no single mining firm in the province of Orientale that had not acquired the services of the commercial security industry. As commercial security firms are by law prohibited to be armed with firearms, the state security agents are procured to supplement commercial security personnel deployed at the premises of the extractive firms.

Commercial security firms would also come to be involved around the non-governmental organizations and international organizations that are engaged in the activities of humanitarian aid, disas- 
ter relief, and other developmental undertakings. Indeed, the first indicator of the presence of a non-governmental organization or an International organization is the presence of the commercial security personnel that patrol premises, manning gates, or handling compound watchtowers. For example, in Goma, the United Nations (UN) and its agencies procure about $30 \%$ of all commercial security personnel [78]. All expatriates in its employment or by its agencies are required to hire commercial security personnel at their residence, selected from a list of the UN approved security service providers, and have the costs compensated by their respective employer or the UN. As a consequence, commercial security personnel in military-looking attires blockade whatever which has no looks of a Sport Utility vehicles (SUV) from accessing watch-towered, barbed wired, and humanitarian spaces [77]. Same as with the mining activities, the 'human' component of the non-governmental and International organization's security arrangement is every so often supplemented by the armed state security agents as the law does not allow commercial security firms to carry firearms. Despite the availability of the police in Goma to be hired for around USD 100 monthly, anyone in Goma can hire an armed police agent, customers do not bypass commercial security firms, firstly, because the commercial security guards are trained better and are more disciplined therefore they are fundamental to abiding by protocol. Secondly, commercial security firms have more infrastructure capabilities: motorized logistics and communication technologies that the state security agents have a deficiency.

The practice of CSFs employing former rebels might constitute a probable liability. But it might also give surety to informal ties to active rebel links, allowing CSFs to preserve current network rebels. This association to some of the conflict players who might be a source of threats to their customers can help in pre-empting and calming security-related concerns before they reach the gates of the consumer's compound without the customer formally knowing [78]. This becomes an advantage of being a commercial entity because positions of responsibility and liability become dispersed through blurred layers of confidential contacts.

It has been argued that we should not even refer to the commercial security industry in the DRC as 'private security' [78]. This is since, because CSI in the DRC offers intricate services such as complex construction and upkeep, gathering of intelligence, risk advisory consultancies, and logistical support [78]. From that perspective, CSI provides 'producer services', that is, a mix of logistics and infrastructure safeguarding services that make the principal business operations in a wide variety of environments possible [76]. The CSFs are very much enthusiastic to fit into this definition. The CSI consequently, has germinated a cumulative tendency towards 'binarization' $[18,3,34]$. Bunkerization is the provision of secure spaces (both physical and time-defined) in where consumers feel free and safe, they are helped to secure their properties: buildings, revenue, plant, product, personnel in addition to intangibles for instance reputation.

If the argument follows, the landscape of commercial security firms clusters around technical infrastructures that make mining possible, then by extension the responsibilities of commercial security firms transform the political order in DRC by the maintenance of infrastructural mediated extraverted political ordering patterns. This entails that, the commercial security sector is a part of a collection of critical infrastructure security, maintenance of logistics which centers significantly on securing systems considered key to domestic political order. What this means is that the progressive dislodging of the DRC's critical infrastructures from the domestic political order and their wedging in an international, commercially secured, political order [78]. And rather than covering the whole of the territory of DRC, this order is hemmed in within the geographical confines of the geography of internationalized 'bunkered zones'.

Commercial security practices in the DRC can have inadvertent adverse consequences. Specifically, the involvement of commercial security entities in the UN's security administration adds to three consequences: first, the hardening of UN's security stance, the differentiation of security between expatriates and the locals and the preservation of insecurity done by the evolution of a local security economy [43]. The commercial security industry in the Democratic Republic of Congo is therefore involved in breeding forms of insecurity that are in several forms entirely divergent to the objectives of national security of protecting civilians and facilitation of sustainable peace. 


\section{Commercialized Security and its role in Tanzania's National Security}

Commercialized Security is a booming industry in the Tanzanian economy. In the past two decades, it has experienced tremendous growth and transformation. The industry provides security personnel and police-type security services, in some way, being more numerous than the national police force. Which composes both the local and international actors began in 1981 with only two companies [80]. Tanzania's security industry was liberalized in the 1980s, and requirements for private security has henceforth been enhanced by the growth of large-scale extraction of minerals and discoveries of natural gas reserves. However, in 2009 there were 360 companies and in 2010 the number increased to 495 companies, countrywide [47]. That figure constituted firms dealing in manned guarding, CVIT, security consultancy, but it did not involve firms dealing in private investigation in addition to night watchmen and bouncers whose number has not been determined by the Police Force [80].

Towards the end of 2014, the chairman of the Tanzania Security Industry Association informed that around 800 private security firms were operating in the nation, with an estimated two million personnel in employment [92]. This number exceeded the Tanzanian police force 41,560 police agents [69]. The Tanzanian police agencies, for that reason, work in partnership with the CSI to provide security services to the state's buildings and institutions such as currency exchange bureaus and various establishments

There was the commercialization of some communal policing engagements that offered ways to moderate the expenses of dispensing community-based security services and develop sustainability. The residents were contributing some money as a means by which the security service was be enhanced those who made the rounds in their neighborhoods. The night patrols generated enhancements in observed security in private and public places that favored all citizens [13]. However, many residents could not afford the services for which they had to finance with an additional fee. This worked against the objective of the whole program as the citizens were not reporting crimes to the commercialized community police.
Each of the firms is accountable for putting in place its professional principles, including on their recruitment, training and development, rules of protocol and behavior, and supervision of firearms. But the lack of legislation makes it problematic to hold firms culpable as there exist occasions of gross professional malpractice by the security service providers and their staff. CSF personnel has been reported being involved in criminality as a consequence of low and late salaries [80]. Therefore, the industry has developed into the origin of insecurity, as security guards conspire with criminal elements [80]. This raises the queries as to the role of the commercialized security industry in Tanzania which is supposed to be founded on fostering security for the people and their assets.

Commercial security personnel are lawfully equipped with shotguns and semi-automatic pistols, but it is illegal to be armed with rifles or automatic pistols which are reserve for the state security officers [69]. The management of the CSFs is responsible for the supervision of these firearms but due to the missing legal framework existing for this, it leads to some cases of misuse of firearms. For example, being used or hired to criminal and complicity of commercial security personnel in participating causing insecurity. Due to the proportion of the sector, and the absence of regulatory policy on this domain, it is probably irresponsible. Arming of CSFs, without doubt, escalate the proliferation of firearms in Tanzania and it should be avoided at all costs. Since CSF agents have very limited or no training at all in human rights, those firearms could easily be misused [69].

In Tanzania, it has been observed that commercial security firms are founded and managed by former military and former police officers with political connections consequently, in one way or another, they can block any move towards effective regulation by [80]. The commercial security actors can feed in positively to the delivery of security within a nation. Nevertheless, an unrestrained or a loosely regulated industry can be a hindrance to the maximum achievement of the objectives of the industry. A major restructuring of the commercial security sector, including the enacting and implementation of legislation to control the sector, would probably improve the security environment in the nation. 


\section{Commercialized Security and its role in Uganda's National Security}

In Uganda, the free market economy in 1998 led to the acquisition of private assets by people and various entities. These acquirements resulted in an increased rate of criminality which consequently let to the need for the delivery of commercialized security to these individuals and various entities. Presently, there are 58 registered commercial security firms in Uganda, with a majority of them also having operations in other African states [30]. There is currently 17,000 commercialized security personnel certified and regulated by the Uganda Private Security Organizations Association [30]. Sakira is quoted as stating that, the police/people ratio remains very low and stands at 1:1473 people [30]. This is below the international ratio, which is $1: 400$. Sakira is also quoted as affirming that, with such a low ratio, combined with insufficient assets in the police agencies, concerns of the police force ineffectiveness and inefficiency are widespread, particularly from those owning properties [30]. It was for that reason that, it was found necessary to collaborate with the state security agencies in some of their functions as one way of addressing the problem. The commercialized security in Uganda is governed by the Police Regulations of 2004. The CSFs that are allowed to engage in business in Uganda, are characterized as per the categories prescribed in Schedule III of the Regulations by the Inspector General of Police. The CSFs are allowed to perform certain services like investigations, manned guards, CVIT escorts, and patrols, and surveillance to protect against insecurity. For each of the categories of the security business, there is a separate license for it.

Communities are inspired to provide security for themselves by establishing solutions for instance communal patrols, target removal, target hardening, and neighborhood watch. Where the public is not able to implement their security using these techniques, they are advised to procure the services of CSFs. In Uganda, the conviction of decreasing the workload of the police force is what stimulated the increasing numbers of CSFs [30].

Uganda has a huge population, and this escalates the requirements for safeguarding. The state security agencies are not entirely sufficient to give assurance of the same, and consequently, commercial security industry complements. Hiring commercial security personnel in Uganda is sensible from a business perspective for the most organization because it is relatively economi- cal [27]. It is undoubtedly inexpensive than engaging the state security personnel. Moreover, hiring commercial security personnel has developed into an 'industry standard', especially for retail and wholesale businesses, since the proprietors are taking due diligence and being cautious, and engaging with CSFs with reputation and trust as the two main criteria in the selection, rather than quality or pricing. CSFs work jointly with the state security agencies. The Ugandan law envisions that the two sectors should supplement each other in protecting both life and property.

Subsequently, the Inspector General of Police is compelled to administer annual performance certificates to CSFs, specified in schedule $V$ of the Regulations, and can be either as exemplary, very good, good, satisfactory, or poor. The InspectorGeneral of Police plays a supervisory role by setting the principles of performance and ensures that they are fulfilled. For instance, adherence to government guidelines on security, minimal risks to the personnel of CSFs and appropriate custody, use, and disposal of firearms and ammunition

The Regulations also stipulate for the collaboration between the CSFs and the state security agencies, instructing that the CSFs to keep regular contact with the state security agencies and to report any incidents of security in nature that might require the expertise of the state security agencies. Under the regulations, the CSFs have been sternly obligated to deliver quality services to their customers. CSFs are engaged to deliver security services to individuals and their assets. They are deployed to safeguard the banks around the clock, and with emphases with the entrances. Also, some learning institutions like secondary and primary schools have them guarding the gates. The CSFs also secure their gates for the state's organizations throughout the day and night [30]. The forex bureaus in Kampala also utilize these services to ensure their security by having the security guards at the entries.

In Uganda, whose sole business is the CVIT service as some of them have a specialty in it but also provide other services as well, for example, Securicor and Security Tight [30]. The CSF agents in Uganda, and especially those assigned to CVIT and manned guarding services, are easier to identify since it is a requirement for them by law to wear uniforms. Sakira is quoted as stating that, CSF vehicles are also easier to identify due to their names, colors, and logos which are in- 
scribed on them, and most of the CVIT vehicles are monitored by their controls or by use of tracking companies [30]. But their main struggle is the involvement of their guards in robbing their customers' valuables, and by detouring vehicles and robbing the valuables in transit [30]. For example, commercial security personnel employed by Securicor Grey stole USh 1.2 billion (equivalent to US\$ 690 million) belonging to Stanbic Bank, which was being ferried from Mbale to Kotido, and only USh 900 million (US\$ 517 000) was redeemed [30]. In another occurrence, a CVIT vehicle transferring USh 700 million (US\$ 402 000) from Mbale to Iganga was detoured, and the monies were taken by security crew employed by for Securicor Grey, and in all these thefts the CVIT vehicles were eventually dumped in case they get be tracked [30].

The main disadvantage in Uganda is that, due to the rapid development of the CSFs, many of the firearms in distribution have been used to execute criminal activities, and also they have been given to crooks. The commercial security firms have also been directed to stop deploying one armed security guard at duty stations but despite that, it has continued. The result has been that many of the security guards have been victims of attacks as others lose their lives and some guns being stolen by criminals. A second disadvantage is that some former state security agents have found new employment in CSFs and they use their knowledge when they were in the security set-up of the country to scheme thefts.

The Ugandan police are authorized to regulate the commercial security industry in their recruitment, training, and other operations. Private security regulation is placed under Chapter 303 of the Police Act (Section, 72) under statutory instrument No. 8. Whereas the registration of CSFs is undertaken by the registrar of companies on the endorsement of the Inspector General of Police (IGP).

\section{Commercialized Security and its role in Kenya's National Security}

Both the escalation of criminality and the development of the commercialized security sector in Kenya can solidly be attributed to the wearing off of the government capabilities that had commenced in the late 1980s and continuing all through the 1990s [2]. For Kenya, as for so many other African countries, this was a period of de- clining economic prosperity, state expenditure and investment were drastically reduced, often in line with international donor requirements for economic liberalization and structural adjustment [2]. The result was a continuing deterioration of the ability of government and municipal institutions to deliver services, including the provision of law and order. As the capacity of the state declined, so too did its previous ability to provide employment, contributing to a rapidly expanding problem of urban unemployment and swelling informal settlements around major cities [21]. Crime in Kenya, and particularly in the capital, rose sharply to the extent that crime levels in Nairobi got to higher levels. A Crime and Safety report by the US Department of State's Bureau of Diplomatic Security Kenya in 2017, identified home invasions, burglaries, armed carjackings, kidnappings, and street crimes, as the most common crimes in Kenya's major cities, and in particular, Nairobi. The UN, whose agencies have a large presence in Nairobi, reported that the number of burglaries in Nairobi doubled to 300 from the last quarter of 2013 to the first quarter of 2014 (Kenya National Commission on Human Rights, 2014). Also, the national police service annual crime report (2016), reported that the number of crimes as having increased by $6 \%$ increase in the year 2015 to 2016 which increased to $1 \%$ in 2017 , and in the year 2018 there was an increase of 13\% (National Police Service, 2018). These are some of the reasons that have precipitated the rapid growth and development of the CSI in Kenya.

Also, the Kenyan Private Security sector has expanded in recent years due to events such as the Kikambala hotel bombing in 2002 and the Westgate terrorist attack in 2013, contributing to the feeling of insecurity in Kenya [56]. This then resulted in a proliferation of commercialized security providers, with some 2000 security firms operating in the country, and large sections of the population relying on commercial security providers for their everyday safekeeping [41, 56]. Accordingly, there were nearly $450 \mathrm{CSF}$ in Nairobi alone that's having the highest concentration [48]. The commercialized security sector is a major source of employment in Kenya, and it is currently estimated that the sector employs 48,811 people [2].

In reality, the state security agencies in Kenya are not able to combat crime unaided with a population of about 47 million people [88], and the National Police Service 2013-2018 Strategic Plan is 
clear in terms of involving partners in combating insecurity in Kenya but it is not precise on the roles of the partners in it. The Private Security Regulation Act No. 13 of 2016, Part VI - Cooperation with National Security Organs, Section 45 on Duty to cooperate states that,

1) Whenever called upon by a national security organ, the Inspector General of the National Police Service, or the Cabinet Secretary, a commercial security service provider shall cooperate in the maintaining law and order or any additional method as would be the desired request.

2) The Cabinet Secretary in consultation with the Inspector-General and the Authority shall make regulations generally to provide for any matter relating to the cooperation, scope, mechanism, and command during the collaboration with the commercial security service players.

For crime mitigation in Nairobi County, the citizenry opts for CSFs for their security requirement [22]. The CSFs are seen to be able to modify their packages to every individual consumer, not like the state security agencies who attend to the public mutually. There are recognized five types of crime mitigation services delivered: residential security, mobile patrols, alarm response, security surveillance in branded security automobiles at vital locations, and screening the access of the public to buildings [23].

A study on the four services of commercial security: manned guarding, alarms and electronics, CVIT and investigation indicated that, overall, the role of the services combined account for $9.3 \%$ of national security [51]. Therefore, manned guarding contributed $26 \%$ of the $9.3 \%(B=.260, \beta=$ $.135, \mathrm{P}=.007)$, alarms and electronics as security service adds $22.9 \%$ of the $9.3 \%(B=.229, \beta=$ $.224, \mathrm{P}=.001$ ), and CVIT adds $10.8 \%$ of the $9.3 \%(\mathrm{~B}=.108, \beta=.118, \mathrm{P}=.018$ ). But commercial investigative security service had no significant role on national security $(B=.036, \beta=.084$, $\mathrm{P}<=$.103) [51].

According to [39] the security situations in the nation would significantly progress with a better regulated CSI alluding to the significance of a controlled sector. This would be an implication that some of the services provided by CSI might not be in sync with national security, thereby necessitating a need to bring them into line with the security of people and their property. In Kenya, the activities of commercialized security are under a code of conduct for security service providers set by the Private Security Regulation Act,
No.13 of 2016. It paved the way for the formation of an authority to oversee the practice of commercialized security in the country by making it accountable and responsible. But as at current, the authority is still yet to start operations.

\section{CONCLUSION}

It is apparent from the deliberation so far that, the phrase 'commercial security' integrates a limited assortment of security activities that the consumer contracts and pays the provider to fulfill. This includes the deployment of manned guards; the production, trade, fitting and maintenance of electronic security devices that citizens may procure to safeguard their home environment and institution, for example, locks, turnstiles, alarms, CCTV, fences); the transportation of cash and valuables and investigation and consultation services. While the conventional attribute of commercialized security can be determined, the circumstance and uniqueness of each nation and each region remain unique and of importance.

The study shows that the commercial security industry is developing and growing rapidly, and currently has larger numbers of personnel than the conventional police agencies. The security landscape is changing as over the years, states have increasingly outsourced to the commercial sector, those roles that do not require to be carried out by the state security agencies. The scope of state security agents has expanded thereby requiring the focus of scarce state security agent's proficiency on operational undertakings that are an exception of states. Realistically, the state will not be losing its monopoly of violence, but subcontracting and distributing it with the commercialized players, be it through networked governance or partnerships.

It is not just man-guarding, but the delivery of a whole range of functions in the area of training, mentoring, and support that the CSI can seek to support the states. This significant feature of commercialized security uses technology to improve their competence in aiding the state to battle insecurity. The CSFs have corporate knowledge of the surroundings and the culture therein, in addition to local links and connections. This trend will continue and will be of real and direct benefit to the state's ability to influence the security. International law regulation of commercial security should also be thought of, given that matching predicaments face countries in both 
continents, for example, Europe, America, Asia, and Australia. There will also be a need for knowledge and confidence to enable this partnership.

Consequently, commercialized security is part of the security landscape of the future. The study recommends that in practice, commercialized security arrangements have agents of public order folded into them, therefore disrupting the truth of the notion 'private' for these engagements.

\section{REFERENCES}

1. Abrahamsen, R., \& Leander, A. (Eds.). (2015). Routledge Handbook of Private Security Studies. London: Routledge. doi: 10.4324/9781315850986

2. Abrahamsen, R., \& Williams, M. (2010). Security Beyond the State: Private Security in International Politics. Cambridge: Cambridge University Press.

3. Appel, H. C. (2012). Walls and white elephants: Oil extraction, responsibility, and infrastructural violence in Equatorial Guinea. Ethnography, 13(4), 439-465. doi: 10.1177/1466138111435741

4. Australia - New Zealand Counter-Terrorism Committee. (2017). Australia's strategy for protecting crowded places from terrorism. Retrieved from https://www.nationalsecurity.gov.au/Mediaand-publications/Publications/Documents/Australias-Strategy-Protecting-Crowded-PlacesTerrorism.pdf

5. Authorities for Protecting Public Safety (Israel), Amendment No 5 and Temporary Provision Law 5776. Retrieved May 1, 2020, from http://knesset.gov.il/privatelaw/plaw_display.asp?LawTp=2

6. Baker, B. (2013). Security Beyond the State: Private Security in International Politics. International Peacekeeping, 20(1), 118-119. doi: 10.1080/13533312.2012.761852

7. Bayley, D. H., \& Shearing, C. D. (1996). The Future of Policing. Law \& Society Review, 30(3), 585. doi: $10.2307 / 3054129$

8. Bergin, A., Williams, D., \& Dixon, C. (2018, October). Safety in numbers: Australia's private security guard force and counter-terrorism. Retrieved from https://www.asial.com.au/documents/item/1645

9. Boemcken, M. (2011). Commercial Security and Development: Findings from Timor-Leste, Liberia and Peru. Retrieved from https://www.bicc.de/uploads/tx_bicctools/brief45.pdf

10. Braverman, I. (2016). Checkpoint Watch: Reflections on Israel's Border Administration in the West Bank. SUNY Buffalo Legal Studies Research Paper, 2012-04. Retrieved from http://ssrn.com/abstract=2016200

11. Burstein, H. (1994). Introduction to Security. Englewood Cliffs: Prentice Hall.

12. Button, M. (2014). Doing Security: Critical Reflections and an Agenda for Change. Basingstoke: Palgrave Macmillan.

13. Cross, C. (2016). Ulinzi Shirikishi: Popular Experiences of Hybrid Security Governance in Tanzania. Development and Change, 47(5), 1102-1124. doi: 10.1111/dech.12261

14. Cunningham, W. C., Taylor, T. H., \& Hallcrest Systems, Inc. (1991). The Hallcrest report: Private security and police in America. Boston: Butterworth-Heinemann.

15. De Goede, M. (2008). Private and Public Security in Post-War Democratic Republic of the Congo. Retrieved from https://issafrica.org/chapter-two-private-and-public-security-in-post-wardemocratic-republic-of-congo-meike-de-goede

16. De Waard, J. (1999). The private security industry in international perspective. European Journal on Criminal Policy and Research, 7(2), 143-174.

17. Dempsey, S. (2010). Introduction to private security (2nd ed.). Belmont: Wadsworth. 
18. Duffield, M. (2010). Risk-Management and the Fortified Aid Compound: Everyday Life in PostInterventionary Society. Journal of Intervention and Statebuilding, 4(4), 453-474. doi: $10.1080 / 17502971003700993$

19. Fischer, R. (2018). Introduction to Security (10th ed.). Amsterdam: Butterworth-Heinemann.

20. Gale Group. (2010). Detective, guard, and armored car services (SIC 7381). Retrieved from https://www.referenceforbusiness.com/industries/Service/Detective-Guard-Armored-CarServices.html

21. Genç, N. (2004). Yönetim ve Organizasyon. Gözden: Çağdaş Sistemler ve Yaklaşımlar.

22. Githimi, S., \& Bor, E. (2015). Private security services and crime control in Karen location, Nairobi County, Kenya. Journal of Humanities and Social Science, 20(10), 84-90.

23. Githimi, S., Bor, E., \& Appolos, M. (2017). How the availability of private security services assist in crime control in Nairobi County, Kenya. Global Journal of Arts, Humanities and Social Sciences, 5(1), 51-61.

24. Goddard, S. (2001). The Private Military Company: A Legitimate International Entity within Modern Conflict (Master's thesis). Retrieved from

https://www.globalsecurity.org/military/library/report/2001/pmc-legitimate-entity.pdf

25. Goldsby, M. 1998. Police and Private Security Working Together in a Co-Operative Approach to Crime Prevention and Public Safety. Canberra: Australian Institute of Criminology. Retrieved April 7, 2015, from http://www.aic.gov.au/media_library/conferences/partnership/golsby.pdf

26. Goldstein, A. (2007, January 2). The private arm of the law Some question the granting of police power to security firms. The Washington Post. Retrieved from https://www.washingtonpost.com/archive/politics/2007/01/02/the-private-arm-of-the-lawspan-classbankheadsome-question-the-granting-of-police-power-to-securityfirmsspan/33dcd4ee-dd51-4473-8ed0-eeb1f8b828f7

27. Gounev, P. (2006). Bulgaria's private security industry. Retrieved from https://pdfs.semanticscholar.org/a14c/d94c0864c4b8696a1c419cc993099acabb52.pdf

28. Graduate Institute of International and Development Studies. (2011). Small arms survey. Retrieved from http://www.smallarmssurvey.org/publications/by-type/yearbook/small-arms-survey2011.html

29. Grimley, M. (2013). An Overview of the U.K.'s Private Security Landscape and Key Security Considerations for U.S. Companies. Retrieved from http://tradeinvest.babinc.org/britam/practical-advice/security

30. Gumedze, S., \& Institute for Security Studies (South Africa). (2007). Private security in Africa: Manifestation, challenges and regulation. Pretoria: Institute for Security Studies.

31. Hareuveni, E. (2014). The Lawless Zone. The Transfer of Policing and Security Powers to the Civilian Security Coordinators in the Settlements and Outposts. Retrieved from http://files.yeshdin.org/userfiles/file/Yesh\%20Din_The\%20Lawless\%20Zone_Web_EN\%20(1).pdf

32. Holmqvist, C. (2005, January). Private Security Companies: The Case for Regulation. Retrieved from https://www.sipri.org/sites/default/files/files/PP/SIPRIPP09.pdf

33. Home Affairs Committee. (2012). Private Investigators. Fourth Report of Session 2012-13. Retrieved from https://publications.parliament.uk/pa/cm201213/cmselect/cmhaff/100/100.pdf

34. Hönke, J. (2013). Transnational Companies and Security Governance: Hybrid practices in a postcolonial world. London: Routledge.

35. Howie, L. (2014). Security Guards and Counter-terrorism: Tourism and Gaps in Terrorism Prevention. Retrieved from https://arrow.tudublin.ie/cgi/viewcontent.cgi?article=1050\&context=ijrtp 
36. IACP/COPS. (2004). National Policy Summit: Building Private Security/Public Policing Partnerships to Prevent and Respond to Terrorism and Public Disorder. Retrieved from https://www.theiacp.org/sites/default/files/all/b/BuildingPrivateSecurity_0.pdf

37. IBIS World (2007). Security and investigative services (except police) in Australia. Melbourne: IBIS World.

38. Joh, E. (2005). Conceptualizing the private police. Utah Law Review, 573-618. Retrieved from https://papers.ssrn.com/sol3/papers.cfm?abstract_id=650945

39. Kaguru, K., \& Ombui, K. (2014). Factors Affecting Performance of Private Security Firms in Nairobi County: A Case Study of G4S Security Services (K) Ltd. International Journal of Science and Research, 3(2), 281-286.

40. Kenya National Commission on Human Right. (2014). A country under siege: the state of security in Kenyan occasional report (2010 - 2014). Retrieved from http://www.knchr.org/Portals/0/CivilAndPoliticalReports/The\%20State\%20of\%20Security\% 20in\%20Kenya.pdf

41. Kitimo, A. (2019, August 11). Security firms race to comply with law ahead of deadline. Retrieved from https://www.businessdailyafrica.com/corporate/companies/Security-firms-race-tocomply-with-law/4003102-5231592-94p5jiz/index.html

42. Kole, O. (2015). Partnership Policing Between the South African Police Service and the Private Security Industry in Reducing Crime in South Africa (Doctoral thesis). Retrieved from http://hdl.handle.net/10500/19153

43. Krahmann, E., \& Leander, A. (2019). Contracting Security: Markets in the Making of MONUSCO Peacekeeping. International Peacekeeping, 26(2), 165-189. doi:

10.1080/13533312.2018.1557051

44. Lottholz, P., \& Lemay-Hébert, N. (2016). Re-reading Weber, re-conceptualizing state-building: from neo-Weberian to post-Weberian approaches to state, legitimacy and state-building. Cambridge Review of International Affairs, 29(4), 1467-1485. doi: 10.1080/09557571.2016.1230588

45. Mazzetti, M. (2009, August 19). C.I.A Sought Blackwater's Help to Kill Jihadists. The New York Times. Retrieved from https://www.nytimes.com/2009/08/20/us/20intel.html

46. Minnaar, A. (2004, December). Crime Prevention, Partnership Policing and the Growth of Private Security: The South African Experience. Retrieved from https://www.ncjrs.gov/pdffiles1/nij/Mesko/207977.pdf

47. Mjingo, H. (November 13, 2010). Female night guards in high risk occupation. Daily News. Retrieved from http://dailynews.co.tz/home/?n=14511\&cat=home

48. Mkutu, K. A., \& Sabala, K. (2007). Private Security Companies in Kenya and Dilemmas for Security. Journal of Contemporary African Studies, 25(3), 391-416. doi: 10.1080/02589000701662442

49. Montgomery, R., \& Griffiths, T. (2015). The Use of Private Security Services for Policing. Research report: 2015-R041. Retrieved from https://www.publicsafety.gc.ca/cnt/rsrcs/pblctns/archive2015-r041/2015-r041-en.pdf

50. Mutonyi, G. P., \& Sirera, A. (2018). Commercial Security's' Effect on Security of Kenyans in Private Venues. Emerging Science Journal, 2(4). doi: 10.28991/esj-2018-01142

51. Mutonyi, G. P., \& Sirera, M. A. (2020). Evaluating the Effects of Commercialized Security on National Security in Nairobi County, Kenya. Path of Science, 6(5), 2001-2022. doi: 10.22178/pos.58-8

52. N. d. (2017). The Kerslake Report. An independent review into the preparedness for, and emergency response to, the Manchester Arena attack on 22nd May 2017. Retrieved from https://www.jesip.org.uk/uploads/media/Documents\%20Products/Kerslake_Report_Manches ter_Are.pdf

53. Nalla, M., \& Newman, G. (2012). A Primer in Private Security. Cork: BookBaby. 
54. National Police Service (2018). Annual crime report. Retrieved from

http://www.nationalpolice.go.ke/crime-statistics.html?download=59:crime-report

55. Nemeth, C. (2018). Private Security and the Law (4th ed.). Boca Raton: CRC Press.

56. Ngugi, W., Kimani, Y., Omondi, E., Wanyama, S., \& Fatuma, A. (2004). Security risk and private sector growth in Kenya: A Survey Report. Nairobi: Kenya Institute for Public Policy Research and Analysis.

57. Noaks, L. (2000). Private cops on the block: A review of the role of private security in residential communities. Policing and Society, 10(2), 143-161. doi: 10.1080/10439463.2000.9964837

58. Oliver, E., \& Wilson, J. (1974). Practical Security in Commerce and Industry. Epping: Gower Press.

59. Parliamentary Joint Committee on the Australian Crime Commission. (2009, June). Examination of the Australian Crime Commission Annual Report 2007-08. Retrieved from https://www.aph.gov.au/binaries/senate/committee/acc_ctte/annual/2008/report/report.pdf

60. Pearce, J. (2017). The Demonic Genius of Politics? Social Action and the Decoupling of Politics from Violence. Retrieved from http://eprints.lse.ac.uk/84458/1/Pearce_Demonic\%20genius\%20of\%20politics_2018.pdf

61. Potgieter, J., Ras, M., \& Neser, J. (2008). Can private security stand up to the challenge of crime and crime prevention in South Africa? A contemporary perspective. Acta Criminologica, 21(1), 33-43.

62. Prenzler, T. (2004). Stakeholder Perspectives on Police Complaints and Discipline: Towards a Civilian Control Model. Australian \& New Zealand Journal of Criminology, 37(1), 85-113. doi: 10.1375/acri.37.1.85

63. Prenzler, T. (2009). Preventing Burglary in Commercial and Institutional Settings: A Place Management and Partnerships Approach. Retrieved from https://www.yumpu.com/en/document/read/25431997/preventing-burglary-in-commercialand-institutional-settings

64. Prenzler, T. (2013). Outsourcing of Policing Tasks: Scope and Prospects. Retrieved from http://www.asial.com.au/documents/item/13

65. Prenzler, T., \& Milroy, A. (2012). Recent inquiries into the private security industry in Australia: Implications for regulation. Security Journal, 25(4), 342-355. doi: 10.1057/sj.2012.2

66. Prenzler, T., \& Sarre, R. (2008). Protective Security in Australia: Scandal, Media Images and Reform. Journal of Policing, Intelligence and Counter Terrorism, 3(2), 23-37. doi: 10.1080/18335300.2008.9686912

67. Prenzler, T., \& Sarre, R. (2012). The Evolution of Security Industry Regulation in Australia: A Critique. International Journal for Crime, Justice and Social Democracy, 1(1). doi: 10.5204/ijcjsd.v1i1.72

68. Provost, C. (2017, May 17). The industry of inequality: why the world is obsessed with private security. The Guardian. Retrieved from https://www.theguardian.com/inequality/2017/may/12/industry-of-inequality-why-world-isobsessed-with-private-security

69. Reisman, L., Mkutu, K., Lyimo, S., \& Moshi, M. (2013, June). Tackling the Dangerous Drift. Assessment of Crime and Violence in Tanzania and Recommendations for Violence Prevention and Reduction. Retrieved from http://www.opensocietyfoundations.org/sites/default/files/tacklingdangerous-drift-20140514.pdf

70. Reno, W. (1999). Warlord Politics and African States. Boulder: Lynne Rienner.

71. Ronen, Y. (2010). Israel: The use and regulation of private military and security companies in situations of armed conflict. Retrieved from http://psm.du.edu/media/documents/reports_and_stats/think_tanks/privwar_nationalreport_ronen.pdf 
72. Ross, A. (2019, June 17). Founder of private security firm Blackwater expands operations in DRC. Business Day. Retrieved from https://www.businesslive.co.za/bd/companies/2019-06-17founder-of-private-security-firm-blackwater-expands-operations-in-drc

73. Rowland, R., \& Coupe, T. (2013). Patrol officers and public reassurance: a comparative evaluation of police officers, PCSOs, ACSOs and private security guards. Policing and Society, 24(3), 265-284. doi: $10.1080 / 10439463.2013 .784300$

74. Sarre, R. (1998). Accountability and the Private Sector: Putting Accountability of Private Security under the Spotlight. Security Journal, 10, 97-102.

75. Sarre, R., \& Prenzler, T. (2011, April). Private Security and Public Interest: Exploring Private Security Trends and Directions for Reform in the New Era of Plural Policing. Retrieved from https://www.asial.com.au/documents/item/12

76. Sassen, S. (2013). The global city: New York, London, Tokyo. Princeton: Princeton University Press.

77. Schouten, P. (2011). Political topographies of private security in Sub-Saharan Africa. Retrieved from https://www.researchgate.net/publication/287252650_Political_topographies_of_private_secur ity_in_Sub-Saharan_Africa

78. Schouten, P. (2014). Private Security Companies and Political Order in Congo: A History of Extraversion (Doctoral dissertation). Retrieved from https://gupea.ub.gu.se/bitstream/2077/35683/1/gupea_2077_35683_1.pdf

79. Schreier, F., \& Caparini, M. (2005). Privatising Security: Law, Practice and Governance of Private Military and Security Companies. Retrieved from https://www.researchgate.net/publication/266317378_Privatising_Security_Law_Practice_and_ Governance_of_Private_Military_and_Security_Companies

80. Shadrack, J. (2011). The private security industry in Tanzania: Challenges, issues and regulation. Retrieved from https://www.academia.edu/9296010/The_Private_Security_Industry_in_Tanzania_Challenges_I ssues_and_Regulation

81. Shemesh, A. (2013). Perspective of the Labor Market for security guards in Israel in time of terror attacks 2000-2004. Retrieved from https://ec.europa.eu/eurostat/cros/system/files/NTTS2013fullPaper_179.pdf

82. Singer, P. (2001). Corporate Warriors: The Rise of the Privatized Military Industry and Its Ramifications for International Security. International Security, 26, 3, 186-220.

83. Sklansky, D. (2006). Private police and democracy. American Criminal Law Review, 43, 89-106.

84. Sparrow, M. (2014). Managing the Boundary between Public and Private Policing. Retrieved from https://www.ncjrs.gov/pdffiles1/nij/247182.pdf

85. The BTI Transformation Index. (2020). Congo, DR Country Report 2020. Retrieved from https://www.bti-project.org/en/reports/country-report-COD.html

86. The Law Enforcement-Private Security Consortium. (2009). Operation Partnership. Trends and Practices in Law Enforcement and Private Security Collaborations. Retrieved from http://www.ilj.org/publications/docs/Operation_Partnership_Private_Security.pdf

87. Travis, A., \& Williams, Z. (2012, March 2). Revealed: Government Plans for Police Privatisation. The Guardian. Retrieved from http://www.theguardian.com/uk/2012/mar/02/police-privatisationsecurity-firms-crime

88. United Nations Office on Drugs and Crime. (2014). State Regulation concerning Civilian Private Security Services and their Contribution to Crime Prevention and Community Safety. Retrieved from https://www.unodc.org/documents/justice-and-prison-

reform/crimeprevention/Ebook0.pdf 
89. Van Dijk, J. (2008). The World of Crime: Breaking the Silence on Problems of Security, Justice, and Development across the World. London: SAGE.

90. Vidulich, C. (1982). Security and Protection Handbook. Johannesburg: International Thomson

91. Waddington, P. A. J. (2007). Plural Policing: A Comparative Perspective. British Journal of Criminology, 48(1), 111-113. doi: 10.1093/bjc/azm065

92. Yankami, W. (2014). Security firms' operations "ungoverned". The Guardian. Retrieved January 20, 2016, from http://www.ippmedia.com/frontend/index.php?l=74494

93. Yorke-Smith, L. (2010, May). The Security Industry Alliance (SIA). Retrieved from http://www.securitysa.com/news.aspx?pklnewsid=35415 